\title{
The Potential of Neural Stem Cell as Vehicle to Deliver Quercus infectoria Extract to Glioma Cell In Vitro
}

(Peranan Sel Stem Neuron sebagai Pembawa Ekstrak Quercus infectoria ke Sel Glioma in vitro)

\author{
TAN SuAT CHENG*, Lohis Balachandran, NorhaZilah MOHAMAD, Kang In NeE, \\ AMIRUL NASARUDIN, RUZI AINI ZAKARIA \& HASMAH ABDULLAH
}

\begin{abstract}
Glioblastoma multiforme (GBM) is the most malignant subtype of brain cancer. However, current clinical treatments for GBM are limited in effectiveness and often impose additional side effects on patients. Here, we developed targeted anti-cancer therapy (TAT) using neural stem cells (NSC) as delivery agent to transport anti-cancer compounds directly to GBM in vitro. Anti-cancer active compounds: Tannic acid (TA) and gallic acid (GA) were extracted from local medicinal plant - Quercus infectoria (QI) using soxhlet technique with 100\% methanol (QI-100\%) or 70\% methanol (QI-70\%) solvent. Concentration of TA and GA measured using HPLC were 72.56 and $43.66 \mu \mathrm{g} / \mathrm{mL}$ in QI-100\%, while in QI-70\%, the concentrations were 72.41 and $43.31 \mu \mathrm{g} / \mathrm{mL}$, respectively. Cytotoxicity effects of QI-100\% and QI-70\% on human GBM cell line (DBTRG-05MG), human NSC line (H9-hNSC) and human normal brain glial cell line (SVG-p12) (as negative control) were determined using MTT assay. Both QI-100\% and QI-70\% showed anti-proliferative properties against DBTRG-05MG at IC ${ }_{50}$, but not on H9-hNSC and SVG-p12. Taken together, data indicated that both QI extracts contained TA and GA which exhibit anti-proliferative effect specifically on cancerous cells only. Next, QI-treated H9-hNSC was seeded in a modified Boyden chamber for $12 \mathrm{~h}$ to investigate its migration capacity towards DBTRG-05MG. The result showed that H9-hNSC migrated towards DBTRG-05MG with 4-folds higher capacity compared to control. In addition, the migration of QI-100\% treated H9-hNSC successfully reduced the number of DBTRG-05MG, indicating the anti-GBM potential of these cells after migration. In conclusion, NSC could be a specific anti-cancer compound delivery agent for GBM, reducing unwanted side effects on patients.
\end{abstract}

Keywords: Glioblastoma multiforme (GBM); neural stem cells (NSC); Quercus infectoria (QI); targeted anti-cancer therapy (TAT)

\section{ABSTRAK}

Glioblastoma multiforme (GBM) adalah sub-jenis kanser otak yang paling berbahaya. Rawatan klinikal pada masa kini adalah terhad daripada segi keberkesanan serta boleh mengakibatkan kesan sampingan pada pesakit. Kajian ini meneliti rawatan bersasarkan kanser (TAT) dengan menggunakan sel stem neuron (NSC) sebagai pembawa sebatian anti-kanser ke sel sasaran GBM. Sebatian anti-kanser: Asid tanik (TA) dan asid galik (GA) diekstrak daripada tumbuhan perubatan tempatan - Quercus infectoria (QI) dengan menggunakan 100\% (QI-100\%) dan 70\% (QI-70\%) metanol melalui teknik soxhlet. Kepekatan TA dan GA hasilan ujian HPLC adalah 72.56 dan $43.66 \mu \mathrm{g} / \mathrm{mL}$ dalam QI-100\%, manakala dalam QI-70\% adalah 72.41 dan $43.31 \mu \mathrm{g} / \mathrm{mL}$. Kesan sitotoksisiti QI-100\% dan QI-70\% terhadap sel GBM manusia (DBTRG05MG), sel NSC manusia (H9-hNSC) dan sel glial otak manusia (SVG-p12) dikaji dengan asai MTT. Kedua-dua QI-100\% dan QI-70\% menunjukkan perencatan populasi sel DBTRG-05MG pada $I_{50}$, tetapi tidak merencatkan populasi sel H9hNSC dan SVG-p12. Data terkumpul menunjukkan bahawa estrak QI mengandungi sebatian TA dan GA yang mempunyai aktiviti perencatan spesifik terhadap sel kanser sahaja. Seterusnya, H9-hNSC yang telah dirawat dengan QI dimasukkan dalam kebuk Boyden terubah suai selam 12 jam untuk tujuan kajian kapasiti migrasi H9-hNSC ke DBTRG-05MG. Data menunjukkan kapasiti migrasi H9-hNSC ke DBTRG-05MG adalah 4 kali ganda lebih tinggi daripada sampel kawalan. Selain itu, migrasi H9-hNSC yang telah dirawat dengan QI-100\% berupaya untuk mengurangkan bilangan sel-sel DBTRG05MG. Ini membuktikan potensi anti-GBM sel berkenaan selepas migrasi. Kesimpulannya, NSC boleh digunakan sebagai agen pembawa sebatian anti-kanser dalam rawatan GBM untuk mengurangkan kesan sampingan terhadap pesakit.

Kata kunci: Glioblastoma multiforme (GBM); Quercus infectoria (QI); rawatan bersasarkan kanser (TAT); sel stem neuron (NSC)

\section{INTRODUCTION}

Glioma is a general term used to describe any brain primary tumor that derived from supportive nerve cells known as glial cells. The main functions of glial cells are to provide protection, nutrients, oxygen, as well as insulation for the neuronal cells. The occurrence of glioma 
can therefore affect the neurons and consequently damage the brain. Glioblastoma Multiforme (GBM) is the most common and malignant subtype of brain tumor (Ramirez et al. 2013). Due to its high degree of malignancy and devastating outcome, GBM is always the top concern in various ongoing scientific researches or clinical trials related to brain cancer, so as in this study. At present, the standard treatment for GBM relies on the effectiveness of surgery and chemo-radiation therapy (Zhang et al. 2012). During surgery, neurosurgeons perform maximal surgical resection of the GBM tumor within safe margins depending on its location. This is to remove as much tumor tissue as possible. Following surgical procedure, the patient undergoes radiotherapy over a period of weeks. The aim is to kill the remaining tumor using high energy beams. As a follow-up, chemotherapy usually is employed. It is reported that patients who received adjuvant chemotherapy with radiotherapy for GBM show greater survival than those who received radiotherapy treatment alone, indicating the importance of chemotherapy to treat GBM (Zhang et al. 2012).

Nonetheless, current chemotherapy treatment regimens are unable to target specifically to GBM tumor tissue partly due to the traditional drug administration route via systemic circulation system which delivers the drug all over body (Ramirez et al. 2013). These drugs indiscriminately kill both normal and cancerous cells, causing unavoidable side effects on the healthy normal cells. These side effects will not only place extra burden on the patients, but also reduce compliance to the treatment. As a consequence, the tumor cannot be completely healed, leading to possible recurrence. Thus, in order to prevent this problem, an alternative chemotherapy targeting glioma specifically to reduce unwanted side effects and increase cancerous cell killing efficiency is necessary.

Recently, targeted anti-cancer therapy (TAT) is gaining a lot of attention worldwide as one of the reliable solution for this issue. Similar to conventional chemotherapy, TAT uses drugs with anti-cancer properties, but instead of inject the drugs systemically, the drugs are packaged in special delivery vehicles which transport the drugs directly to the cancer cells at tumor site. Hence, the TAT only targets the cancer cells and causes less damage to healthy cells. As a result, the patients will not suffer much adverse effects compared to the current chemotherapy. There are several important criteria for the selection of TAT delivery agent; first, the inert reactivity of the agent to the anti-cancer drug; second, the ability of the agent to migrate to the cancer site specifically and third, the ability of the agent to penetrate an intact and functional brain-tumour-cell barrier throughout the entire brain (Argarwal et al. 2011). Here, we aimed to investigate the potential of neural stem cells (NSCs) as delivery agent for TAT in treating GBM.

NSCs are stem cells found abundantly in both brain and central nervous system. They have the ability to self-replicate and to differentiate into specialized cells such as neurons, astrocytes and oligodendrocytes when stimulated (Kornblum 2007). NSCs in adult brain possess unique potential to migrate towards pathologically altered tissue locations in primary brain tumor (Aboody et al. 2000). Genetically modified NSCs also proved to deliver therapeutic proteins such as interleukins to tumor sites (Benedetti et al.2000). However, to date, there is no study to determine NSC's capacity to migrate to GBM cells in vitro carrying an anti-GBM active compound isolated from the galls of a local natural medicinal plant known as Quercus infectoria (QI). QI galls are found on twigs of dyer's oak tree, a tree which can grow from 4 to 6 feet tall (Shrestha et al.2014). These galls are formed due to enzyme stimulation from larva of gall wasp. QI galls contain $50 \%$ to $70 \%$ of tannic acid (TA) constituents followed by gallic acid (GA) and other minor elements such as syringic acid and ellagic acid (Shaikh et al. 2013). TA and GA are the major constituents of QI that have anti-proliferative activities against cancer cells. In previous study, TA and GA extracted from QI were found to have anti-proliferative properties against cervical cancer cells (HeLa) and ovarian cancer cells (Caov-3) (Hasmah et al. 2010). This is the first study to investigate cytotoxivity effect of QI extract on GBM and the capacity of NSCs to deliver this potential anti-GBM extract to human GBM cell line in vitro.

\section{MATERIALS AND MeTHODS}

\section{CELL CULTURE}

Cancerous human GBM cell line (DBTRG-05MG) cells were cultured in a T25 tissue culture flask filled with $2 \mathrm{~mL}$ of complete media composed of Roswell Park Memorial Institute (RPMI) media supplemented with $10 \%$ heat inactivated fetal bovine serum (FBS) and 1\% penicillinstreptomycin antibiotics (pen-strep) at cell density of 1 $\times 10^{5}$ cells/flask. On the other hand, human neural stem cell line (H9-hNSC) were cultured in a T25 tissue culture flask filled with complete media composed of StemPro NSC Serum free media supplemented with KnockOut DMEM/F-12, 1.0\% GlutaMAX-I supplement, 0.02\% basic fibroblast growth factor (bFGF), $0.02 \%$ Epidermal growth factor (EGF) and $2.0 \%$ StemPro Neural Supplement at cell density of $1 \times 10^{5}$ cells/flask. The flasks used to culture H9-hNSC cells were pre-coated with CELLStart and incubated an hour at $37^{\circ} \mathrm{C}$ before transferring $\mathrm{H9}$ hNSC cells. Normal human glial cell line (SVG-p12) was also used in this study as negative control. This cell was cultured in Eagle's Minimum Essential Medium (EMEM) complete culture media supplemented with FBS and 1\% pen-strep at cell density of $1 \times 10^{5}$ cells/flask. All the cell culture flasks were incubated in humidified incubator with $5 \% \mathrm{CO}_{2}$ at $37^{\circ} \mathrm{C}$ for $24 \mathrm{~h}$. Used media was replaced with $2 \mathrm{~mL}$ fresh complete media every two days and cultured until confluency.

\section{PLANT EXTRACTION}

QI gall powder was prepared as described in previous study (Baharuddin et al. 2015). $15 \mathrm{~g}$ of the QI powder 
was transferred into thimble added with $450 \mathrm{~mL}$ of $100 \%$ methanol (QI-100\%) or 70\% methanol (QI-70\%) solvent. The temperature of the extraction was set at the boiling point of methanol $\left(64.7^{\circ} \mathrm{C}\right)$ and the extraction was carried out for $6 \mathrm{~h}$. The methanol from the extract was removed using rotary evaporator at $40^{\circ} \mathrm{C}$ until the extract completely dried. The yield of both QI- $100 \%$ and QI- $70 \%$ were calculated using the following equation:

$$
\begin{aligned}
& \begin{array}{l}
\text { Percentage of yield } \\
\text { extraction }(\%)
\end{array} \\
& \text { Final weight }(\mathrm{g})
\end{aligned} \times 100 \%
$$

\section{DETERMINATION OF PHENOLIC COMPOUNDS IN QI METHANOL EXTRACTS}

Concentration of phenolic compounds in QI-100\% and QI-70\% were determined using high performance liquid chromatography (HPLC) with TA and GA as standard markers. The flow rate of mobile phase was $1.0 \mathrm{~mL} / \mathrm{min}$ and the detection wavelength was $280 \mathrm{~nm}$. For TA HPLC assay, Poroshell 120 EC-18 $(4.6 \times 50 \mathrm{~mm})$ was used as stationary phase while methanol (solvent A) and $1 \%$ of acetic acid (solvent B) were used as gradient system. The gradient system for TA HPLC assay started with $60 \%$ solvent A, followed by $35 \%$ solvent $\mathrm{A}$ and $10 \%$ solvent $\mathrm{A}$. Then, the gradient ended with $60 \%$ of solvent $\mathrm{A}$. Whereas for GA HPLC assay, Zorbax Eclipse Plus C18 (4.6×150 mm) was used as stationary phase while methanol (solvent A) and $4 \%$ acetic acid (solvent B) were used as gradient system. The gradient system for GA HPLC assay started with $100 \%$ solvent B, followed by $50 \%$ solvent B and $20 \%$ solvent B. The gradient ended with $100 \%$ solvent B. The peaks of the extracts were identified by comparing them with peaks of the standard markers. The percentage of TA and GA were calculated based on the area under curve (AUC) of QI sample chromatogram, compared to AUC of standard chromatogram. The concentration of the TA and GA of each extracts was calculated using equation below:

$$
\begin{aligned}
& \text { Sample } \\
& \text { concentration }
\end{aligned}: \frac{\text { Area under curve of sample }}{\text { Area under curve of standard }} \times \begin{aligned}
& \text { Standard } \\
& \text { concentration }
\end{aligned}
$$

\section{ANTI-OXIDANT ASSAY}

DPPH (1,1-diphenyl-2-picrylhydrazyl) radical scavenging activity assay was performed with minor modification of previous study (Syukriah et al. 2014). First, $1 \mathrm{mg} / \mathrm{mL}$ QI$100 \%$ and QI-70\% solutions were prepared by dissolving 10 $\mathrm{mg}$ of QI- $100 \%$ and QI- $70 \%$ extract in $10 \mathrm{~mL}$ of methanol, respectively. Then, $2.5 \mathrm{~mL}$ of the extract solutions were added to $2.5 \mathrm{~mL}$ of $0.08 \mathrm{mg} / \mathrm{mL}$ DPPH solution. The tubes were left in dark for $30 \mathrm{~min}$ at room temperature. Blank (control) contained only the methanol was also prepared for DPPH assay. The optical density (OD) of each sample was measured using spectrophotometer at wavelength 517 $\mathrm{nm}$. Triplicates were measured for each sample and average was calculated. Percentage of DPPH radical scavenging was calculated as follows:

$$
\begin{aligned}
& \text { Percentage of } \\
& \text { radical scavenging }=
\end{aligned} \quad \begin{aligned}
& \text { Absorbance control }- \\
& \text { Absorbance sample }
\end{aligned} \times 100 \%
$$

\section{ANTI-PROLIFERATIVE ASSAY}

DBTRG-05MG, H9-hNSCs and SVG-p12 cells were seeded into 96 -well plate at density $5 \times 10^{4}$ cells per well, respectively. Complete media with gradients concentrations $(0,25,50,75$ and $100 \mu \mathrm{g} / \mathrm{mL})$ of QI plants extracts (QI-100\% and QI-70\%) and synthetic drugs (tamoxifen and temozolomide; used as positive controls) were added into respective wells with seeded cells. The plate was incubated at $37^{\circ} \mathrm{C}$ for $72 \mathrm{~h}$. Then, MTT solution $(5 \mathrm{mg} / \mathrm{mL})$ was added into each of the wells. The plates were incubated in humidified incubator with at $37^{\circ} \mathrm{C}$ for $4 \mathrm{~h}$. Absolute DMSO was added into the wells and OD was measured at wavelength $570 \mathrm{~nm}$. The half maximal inhibitory concentration $\left(\mathrm{IC}_{50}\right)$ of each solvent was determined using graph percentage of viable cells against concentration $(\mu \mathrm{g} / \mathrm{mL})$. The percentage of viable cells was calculated using formula as follows:

$$
\begin{aligned}
& \text { Percentage of } \\
& \text { viable cells }(\%)
\end{aligned}=\frac{\text { Absorbance in a well }}{\text { Absorbance of negative control }} \times 100 \%
$$

\section{COLORIMETRIC CELL MIGRATION ASSAY}

Milipore Colorimetric Cell Migration Assay (Boyden Chamber Assay) was used to investigate cell migration. The assay composed of a 24-well plate (bottom chamber) and 24 pieces of insert with polycarbonate membrane of 8 $\mu \mathrm{m}$ pore size (upper chamber). First, the 24 -well plate was seeded with $1 \times 10^{5}$ DBTRG-05MG cells/well and cultured in humidified incubator with $5 \% \mathrm{CO}_{2}$ at $37^{\circ} \mathrm{C}$ for $24 \mathrm{~h}$. Then, used media was aspirated and the cells were washed with $1 \mathrm{~mL}$ sterile PBS to ensure no presence of serum in the wells. The cells were starved by adding $500 \mu \mathrm{L}$ of serum free RPMI media per well and the plate was incubated in humidified incubator with $5 \% \mathrm{CO}_{2}$ at $37^{\circ} \mathrm{C}$ prior to the cell migration assay. At the same time, H9-hNSCs were treated for $24 \mathrm{~h}$ with optimum concentrations of QI plants extracts and synthetic drugs as determined from the previous anti-proliferation assay. After that, the treated H9-hNSC cells were harvested and seeded onto the inserts with polycarbonate membrane at cell density of $7.5 \times 10^{4}$ cells/insert. Negative control insert contained the untreated H9-hNSC and blank insert contained only the serum free medium was also prepared for the assay. All the inserts prepared were transferred to the 24 -well plate pre-seeded with DBTRG-05MG using sterile forceps. Then the whole plate was incubated in humidified incubator with $5 \% \mathrm{CO}_{2}$ at $37^{\circ} \mathrm{C}$ for $12 \mathrm{~h}$. After $12 \mathrm{~h}$, the used RPMI media from the interior of the inserts were removed carefully and cells that have migrated to the bottom of the insert membrane were stained based on manufacturer's protocol. While the DBTRG-05MG at the bottom wells of the 24-well plate were subjected to MTT assay to measure cell viability after migration assay. 


\section{STATISTICAL ANALYSIS}

Data obtained were analysed using SPSS 22.0 for windows. All data were obtained from at least three independent experiments and the analyses of these data were expressed as average value \pm standard deviation (SD). The statistical differences of measurements made in same cell type but different treatments were analysed using a paired T-test, whereas multiple comparisons between different treatments on different cell types were analysed using one-way analysis of variance (ANOVA). A value of $p<0.05$ was considered statistically significant.

TABLE 1. Total extraction yield and total plant extract of QI methanol extracts

\begin{tabular}{ccc}
\hline Type of solvent & $\begin{array}{c}\text { Plant extract yield } \\
(\mathrm{g})\end{array}$ & $\begin{array}{c}\text { Yield } \\
(\%)\end{array}$ \\
\hline QI-100\% & 2.95 & 19.7 \\
QI-70\% & 2.89 & 19.3 \\
\hline
\end{tabular}

\section{RESULTS}

\section{PLANT EXTRACTION YIELD AND ANTIOXIDANT ASSAY}

Both QI-100\% and QI-70\% generated approximately 20\% extraction yield using methanol soxhlet technique. There was no significant different in yield percentage between QI-100\% and QI-70\%, indicating the concentration of methanol solvent did not affect the extraction yield (Table 1). Similarly, free radical scavenging activity was exhibited similarly high in both QI-100\% (97.3 $\pm 1.4 \%)$ and QI-70\% $(96.4 \pm 3.7 \%)$ (Table 2$)$.

TABLE 2. DPPH free radical scavenging activity of QI methanol extracts

\begin{tabular}{cc}
\hline Type of solvent & $\begin{array}{c}\text { DPPH free radicals scavenging } \\
(\%)\end{array}$ \\
\hline QI-100\% & $97.3 \pm 1.4$ \\
QI-70\% & $96.4 \pm 3.7$ \\
\hline
\end{tabular}

A

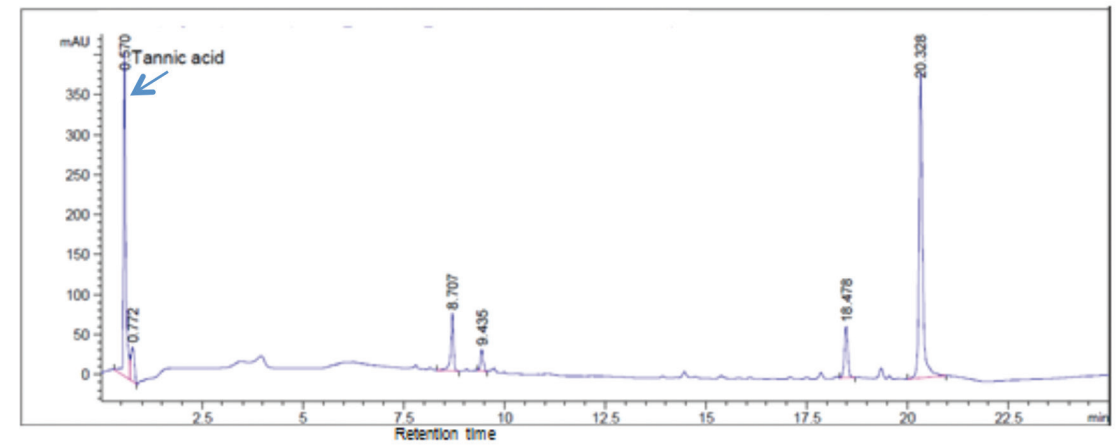

B

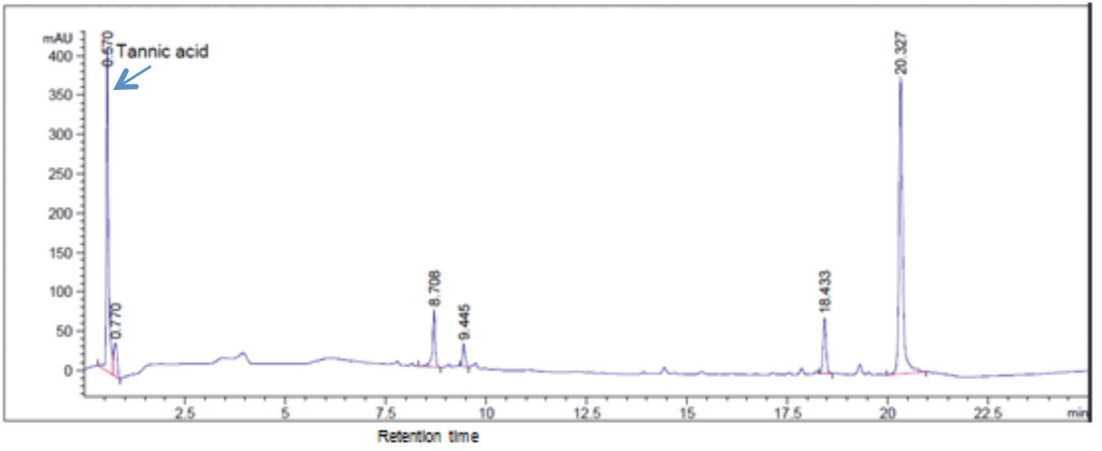

C

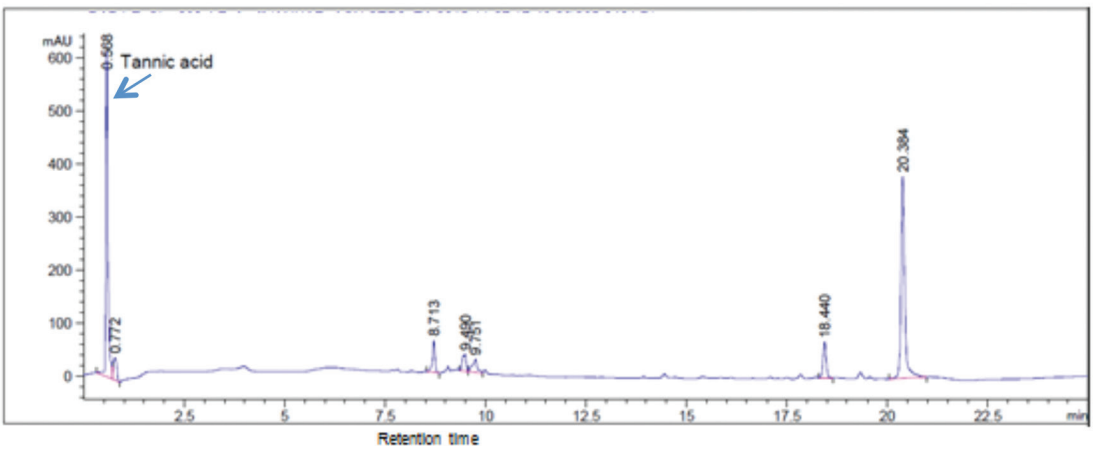

FIGURE 1. HPLC chromatogram of tannic acid (TA) in (A) Q. infectoria $100 \%$ methanol extract (QI-100\%); (B) Q. infectoria $100 \%$ methanol extract (QI-70\%) and (C) TA standard solutions. The clear peak at retention time $\sim 1.5$ min indicated the presence of TA 


\section{HPLC ANALYSIS}

Presence of TA in plant extract was indicated by a clear single peak that was observed at retention time $0.6 \mathrm{~min}$ in both HPLC chromatogram of QI-100\% (Figure 1(A)) and QI-70\% (Figure 1(B)). Table 3 shows a slim different in percentage and concentration of TA between QI-100\% $(1.316 \% ; 72.56 \mu \mathrm{g} / \mathrm{mL})$ and QI-70\% $(1.321 \% ; 72.41$ $\mu \mathrm{g} / \mathrm{mL})$. For GA analysis, a clear peak was observed at retention time $1.5 \mathrm{~min}$ in both HPLC chromatogram of QI$100 \%$ (Figure 2(A)) and QI-70\% (Figure 2(B)), indicating the presence of GA in these extracts. The percentage and concentration of GA did not differ significantly between QI- $100 \%(0.954 \% ; 43.66 \mu \mathrm{g} / \mathrm{mL})$ and QI-70\% (0.949\%; $43.31 \mu \mathrm{g} / \mathrm{mL})$ as listed in Table 4.

\section{ANTI-PROLIFERATIVE ASSAY}

The $\mathrm{IC}_{50}$ for DBTRG-05MG treated with QI plants extracts (QI-100\% and QI-70\%) and synthetic drugs (tamoxiden and temozolomide) were obtained from MTT assay (Figure 3(A)). The data showed that Tamoxifen has the highest antiproliferative activities $\left(\mathrm{IC}_{50}\right.$ value $\left.=9 \mu \mathrm{g} / \mathrm{mL}\right)$ followed by QI-100\% $\left(\mathrm{IC}_{50}\right.$ value $\left.=23 \mu \mathrm{g} / \mathrm{mL}\right)$, QI-70\% $\left(\mathrm{IC}_{50}\right.$ value $=$

TABLE 3. Percentage and concentration of TA extracted from QI methanol extracts

\begin{tabular}{cccc}
\hline Type of solvent & $\begin{array}{c}\text { Area under curve } \\
(\text { AUC })\end{array}$ & $\begin{array}{c}\text { Percentage of TA } \\
(\%)\end{array}$ & $\begin{array}{c}\text { Concentration of TA } \\
(\mu \mathrm{g} / \mathrm{mL})\end{array}$ \\
\hline QI-100\% & 1586.21 & 1.316 & 72.56 \\
QI-70\% & 1582.73 & 1.312 & 72.41 \\
\hline
\end{tabular}

A

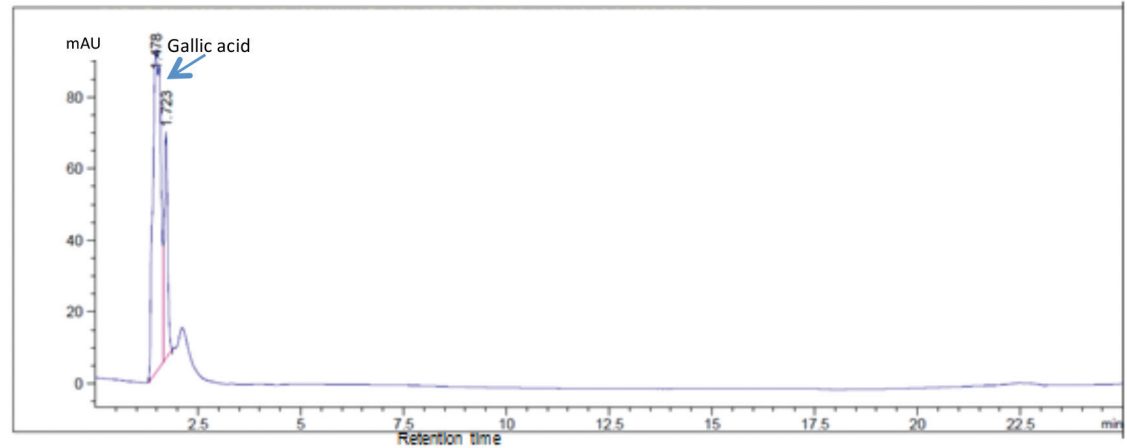

B

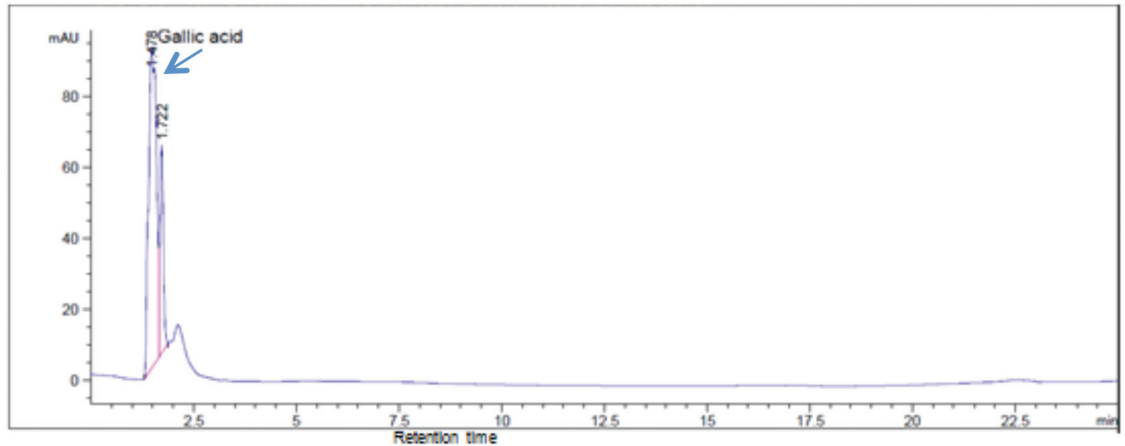

C

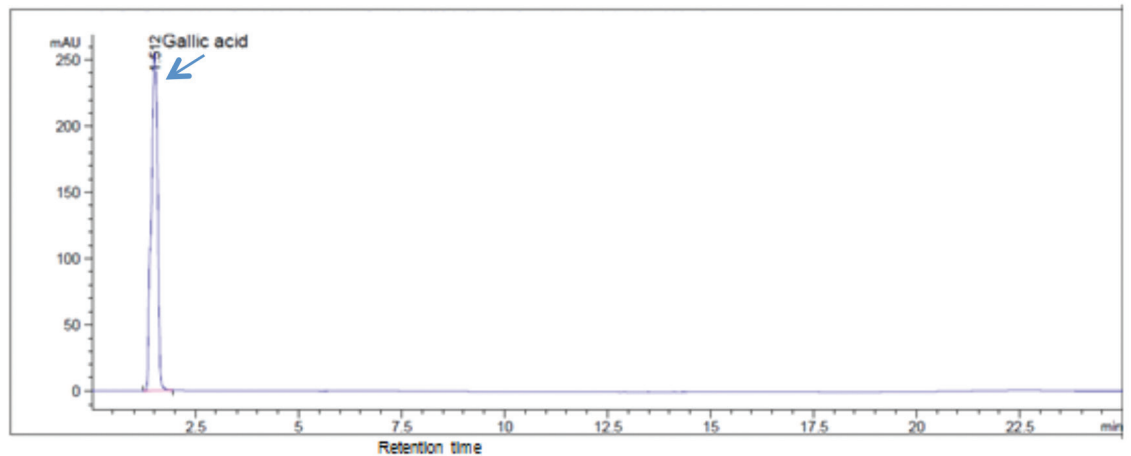

FIGURE 2. HPLC chromatogram of gallic acid (GA) in (A) Q. infectoria $100 \%$ methanol extract (QI-100\%); (B) Q. infectoria $100 \%$ methanol extract (QI-70\%) and (C) standard GA solutions. The clear peak at retention time $\sim 1.5$ min indicated the presence of GA 
TABLE 4. Percentage and concentration of GA extracted from QI methanol extracts

\begin{tabular}{cccc}
\hline Type of solvent & $\begin{array}{c}\text { Area under curve } \\
(\mathrm{AUC})\end{array}$ & $\begin{array}{c}\text { Percentage of GA } \\
(\%)\end{array}$ & $\begin{array}{c}\text { Concentration of GA } \\
(\mu \mathrm{g} / \mathrm{mL})\end{array}$ \\
\hline QI-100\% & 1207.18 & 0.954 & 43.66 \\
QI-70\% & 1197.64 & 0.949 & 43.31 \\
\hline
\end{tabular}

A

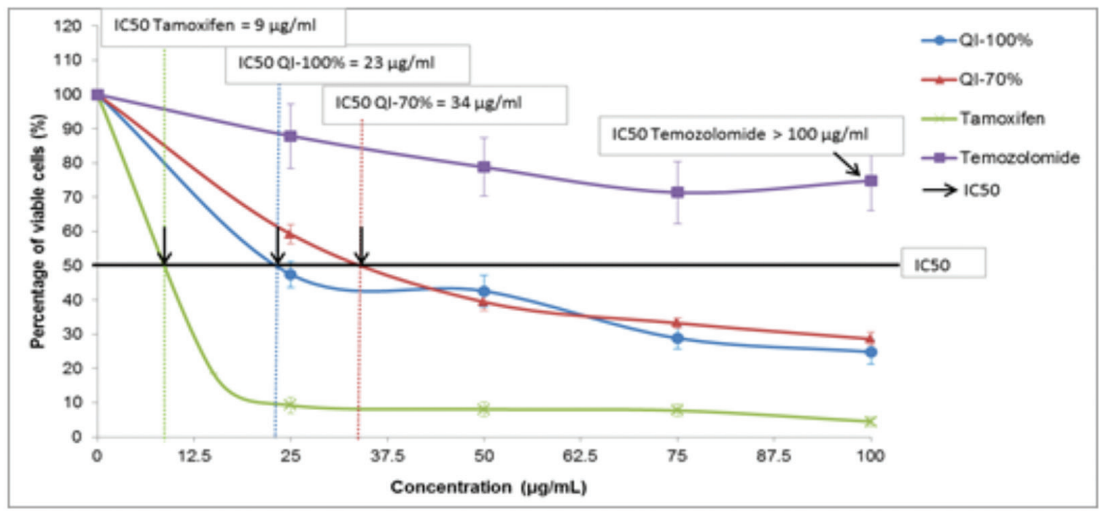

B

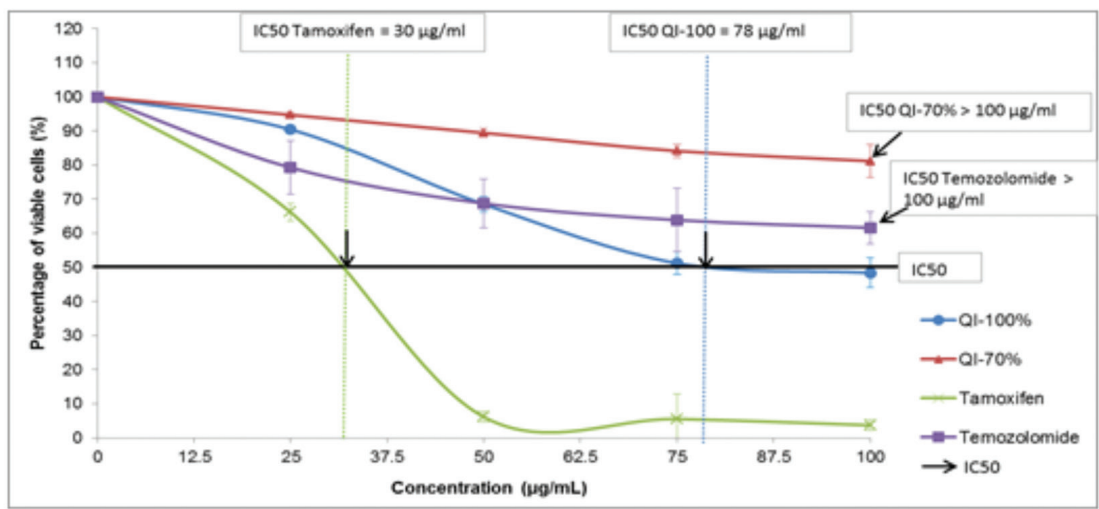

C

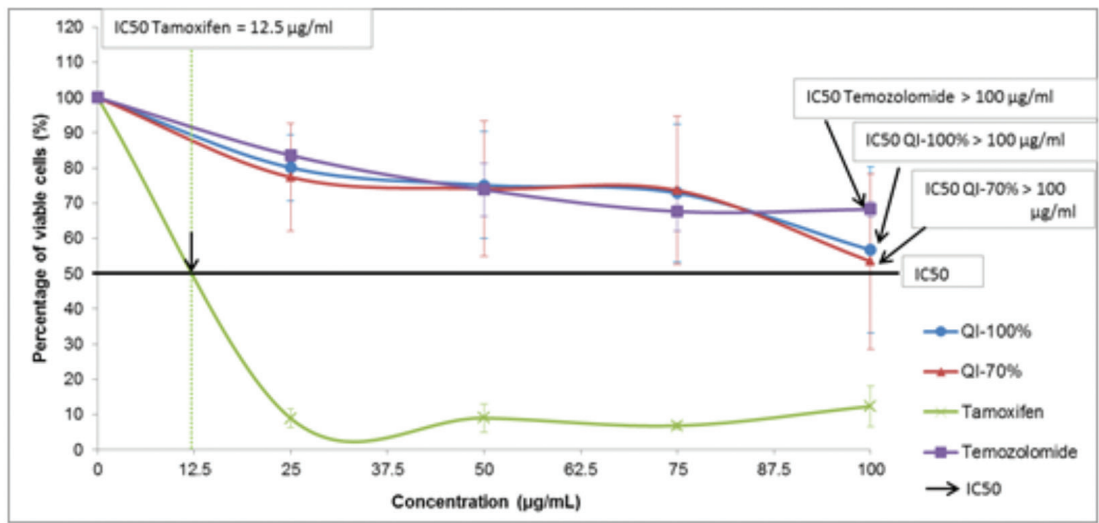

FIGURE 3. Gradient concentrations of QI methanol extracts (QI-100\% and QI-70\%) and synthetic drugs (Tamoxifen and Temozolomide) against percentage of viable (A) DBTRG-05MG cells, (B) H9-hNSC cells and (C) SVG-p12 cells (negative control). Each point is average percentage of viable cells (comparison to negative control, DMSO 1\%) with standard deviation of three independent experiments

$34 \mu \mathrm{g} / \mathrm{mL}$ ) and temozolomide (IC50 value $>100 \mu \mathrm{g} / \mathrm{mL}$ ). Similar trend was found for the other two cell lines: H9hNSCs and SVG-p12 in which tamoxifen has showed the highest anti-proliferative activities followed by QI-100\%, QI-70 and temozolomide (Figure 3(B) and 3(C)). The $\mathrm{IC}_{50}$ value of each the treatments were tabulated in Table 5.
In the comparison between QI methanol extract treatments on cancerous brain cells DBTRG-05MG, QI- $100 \%$ had smaller $\mathrm{IC}_{50}$ value compared to QI-70\% (Table 5; $p<0.05$ ). This indicated that the QI- $100 \%$ extract possibly has higher potent to inhibit glioma growth compared to QI-70\%. On the other hand, in the comparison between 
TABLE 5. IC ${ }_{50}$ of QI-100\%, QI-70\%, tamoxifen and temozolomide on DBTRG-05MG, H9-hNSCs and SVG-p12 and the optimum concentrations selected for cell migration assay

\begin{tabular}{|c|c|c|c|c|}
\hline Treatment & $\begin{array}{l}\mathrm{IC}_{50} \text { for DBTRG- } \\
05 \mathrm{MG}(\mu \mathrm{g} / \mathrm{mL})\end{array}$ & $\begin{array}{l}\mathrm{IC}_{50} \text { for H9-hNSC } \\
(\mu \mathrm{g} / \mathrm{mL})\end{array}$ & $\begin{array}{c}\mathrm{IC}_{50} \text { for SVG-p12 } \\
(\mu \mathrm{g} / \mathrm{mL})\end{array}$ & $\begin{array}{l}\text { Optimum concentration used } \\
\text { in migration assay } \$\end{array}$ \\
\hline Tamoxifen & 9 & 30 & 16.2 & 10.0 \\
\hline QI-100\% & \multirow{2}{*}{$\left.2^{2}{ }^{*}\right\}$} & \multirow{2}{*}{$\left.\begin{array}{c}78 * * \\
>100 * *\end{array}\right\} \#$} & $>100 * * *$ & 25.0 \\
\hline QI-70\% & & & $>100 * * *$ & 35.0 \\
\hline Temozolomide & $>100 *$ & $>100 * *$ & $>100 * * *$ & $\begin{array}{l}\text { Excluded from migration study due to } \\
\text { insensitivity to all cell lines }\end{array}$ \\
\hline $\begin{array}{l}* \mathrm{p}<0.05 \text { vs. Tamox } \\
* * \mathrm{p}<0.05 \text { vs. Tamo } \\
* * * \mathrm{p}<0.05 \text { vs. Tam } \\
\mathrm{p}<0.05 \text { between th } \\
\text { Optimum concentra } \\
\text { cell lines }\end{array}$ & $\begin{array}{l}\mathrm{C}_{50} \text { for DBTRG-05MG } \\
\mathrm{IC}_{50} \text { for H9-hNSC } \\
\text { nIC50 for SVG-p12 } \\
\text { groups linked with arr } \\
\text { for cell migration assay }\end{array}$ & lect & . & DBTRG-05MG but minimal (less than $\mathrm{IC}_{50}$ ) to othe \\
\hline
\end{tabular}

QI methanol extract treatments on normal brain stem cell H9-hNSCs and brain glial cell SVG-p12 (as control), both QI-100\% and QI-70\% showed higher IC $_{50}$ value (Table $5 ; p<0.05)$ compared to cancerous DBTRG-05MG cells, indicating that these extracts were not cytotoxic to the normal cells at a concentration that was cytotoxic to cancerous cells. Taken together, the data indicated that the inhibitory effect of both QI- $100 \%$ and QI-70\% was more potent to cancerous GBM cell line, but less or minimal on normal brain cell lines. These result also illustrated the suitability of NSC as delivery agent for QI-100\% and QI-70\% due to its low or negative reactivity to these plant extracts at a concentrations that could significantly kill the target cancerous GBM cells.

Notably, we found that clinically used anti-cancer drug, tamoxifen, showed $\mathrm{IC}_{50}$ at 30 and $16 \mu \mathrm{g} / \mathrm{mL}$ to brain stem cells and glial cells, respectively (Figure 3(B), 3(C); Table 5). This explained why chemotherapy using clinical anti-cancer drug could cause detrimental side effects on healthy normal cells. On the other hand, another clinical anti-cancer drug, temozolomide, showed $\mathrm{IC}_{50}$ value more than $100 \mu \mathrm{g} / \mathrm{mL}$ for DBTRG-05MG, indicating the minimal inhibitory effect of this drug on glioma cell line even at high concentration. These results suggested that a re-evaluation of temozolomide for clinical use is necessary.

\section{CELL MIGRATION ASSAY}

H9-NSCs showed migration from inferior of the insert into membrane towards DBTRG-05MG cells seeded in the lower chamber after $12 \mathrm{~h}$ incubation on a Boyden migration chamber (Figure 4(A)). There was no H9-hNSCs observed migrated to the lower chamber without DBTRG-05MG (empty lower chamber; negative control) (Figure 4(B)), indicating that the migration of H9-NSCs is specific in direction driven by the cell instinct tropism towards DBTRG05MG. This also indicated that the cell migration was not due to gravity attraction. However, incubation more than $12 \mathrm{~h}$ on a Boyden migration chamber induced excess cell migration in which all cells were eventually attracted to the bottom chamber triggered by gravity force (data not shown).

Therefore, the amount of migrated cells were harvested and counted after $12 \mathrm{~h}$ incubation period. It was found that the migration capacity for $\mathrm{H} 9-\mathrm{hNSC}$ was significantly higher

A

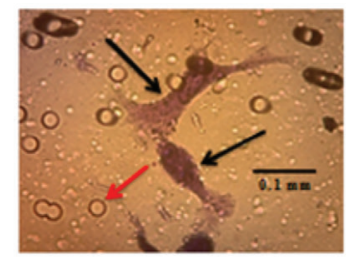

B

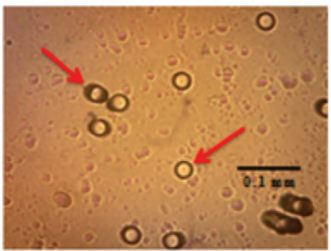

C

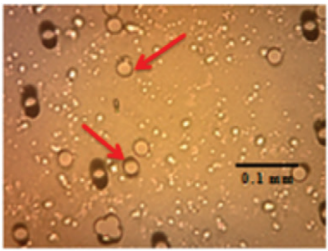

D

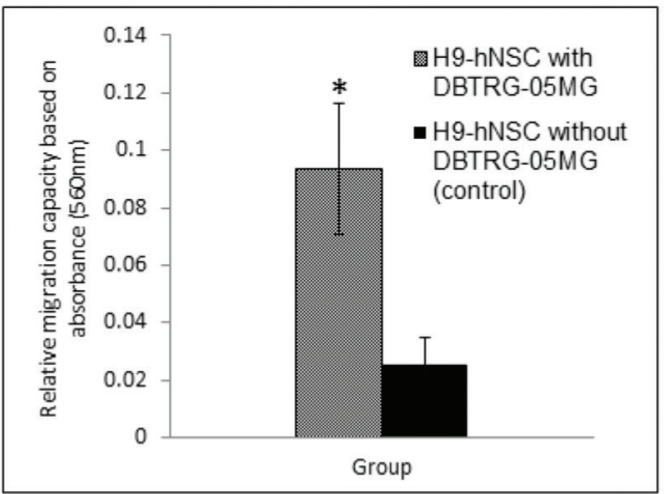

FIGURE 4. Cell migration assay of (A) H9-hNSC with DBTRG05MG seeded at lower chamber (B) H9-hNSC without DBTRG05MG seeded at lower chamber (negative control) and (C) blank (without both H9-hNSC and DBTRG-05MG). Migrated H9-hNSC is indicated by black arrows. Red arrows indicate $8 \mu \mathrm{m}$-sized pores of polycarbonate membrane of the insert. Magnification: 40X. (D) Quantification of migrated H9-hNSC. H9-hNSCs showed significant increase in migration capacity towards DBTRG-05MG. $* p<0.05$ vs. control group 
by about 4-folds towards DBTRG-05MG compared to lower chamber without DBTRG-05MG $(p<0.05)$ (Figure 4(D)).

\section{CELL MIGRATION WITH PLANT EXTRACT}

Based on the anti-proliferative assay, optimum QI-100\%, QI-70\% and tamoxifen concentrations were determined (Table 5). These concentrations were used to treat H9hNSC cells prior to cell migration assay. The concentrations chosen were based on the optimum concentration that able to eradicate more than $50 \%$ of DBTRG-05MG cells but lesser than $50 \%$ of H9-hNSC cells. Temozolomide was excluded from subsequent study due to its ineffectiveness to kill glioma. All QI-treated H9-hNSC and Tamoxifen treated H9-hNSCs showed migration into the membrane of the insert (Figure 5(A)-5(C); black arrows), similar to the untreated H9-hNSCs (negative control) (Figure 5(D); black arrows). The migrated cells were harvested and counted (Figure 5(E)). Data shows that migration capacity of H9hNSCs treated with either QI-100\%, QI-70\% or tamoxifen were not different than the non-treated H9-hNSCs, indicating the treatments did not affect the migration of H9-hNSC cells towards DBTRG-05MG cells. This also indirectly illustrated the suitability of the H9-hNSC cells as delivery agent for QI-100\%, QI-70\% or tamoxifen as the migration of H9-hNSC cells are not affected by any of these compounds. After migration assay, the viability of DBTRG-05MG cells at lower chamber were evaluated using MTT assay. It was found that that DBTRG-05MG treated with migrated H9-hNSCs preconditioned with QI- $100 \%$ showed significant reduction by $20 \%$ in cell viability when
A

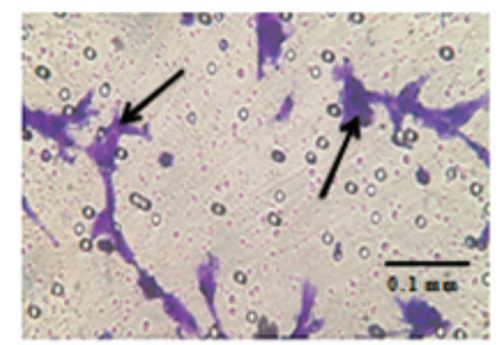

C

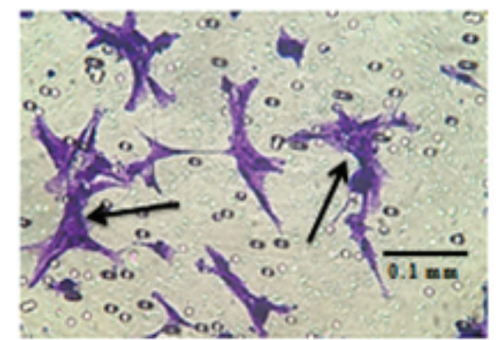

B

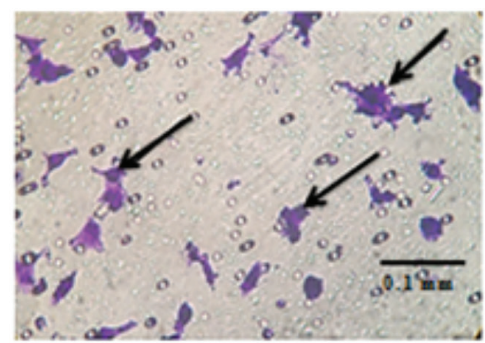

D

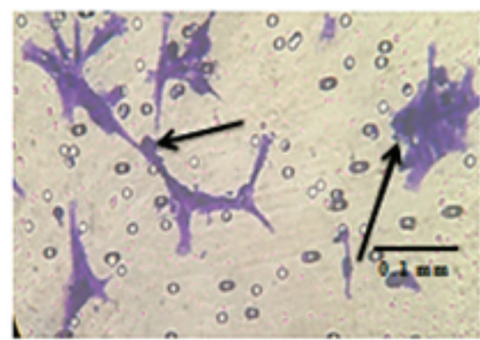

$\mathbf{E}$

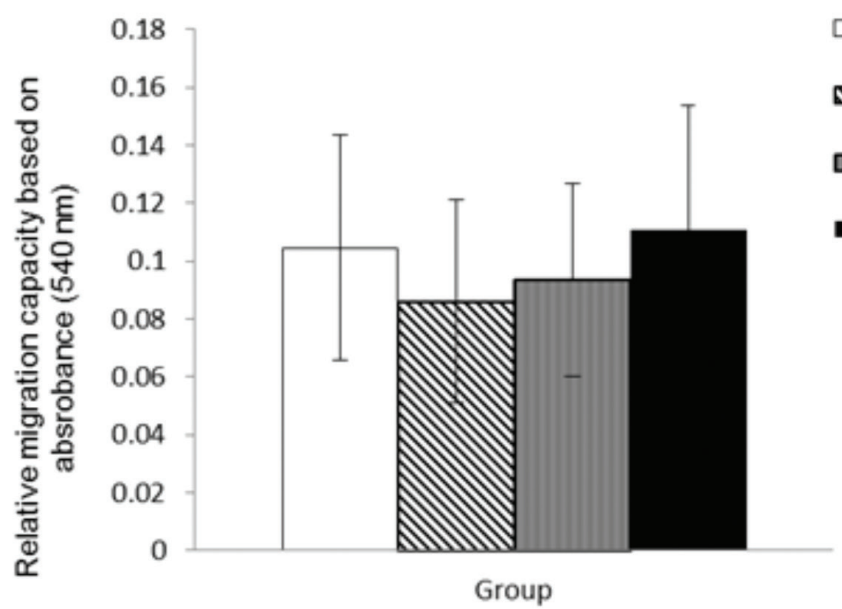

$\square$ Non-treated (control)

QQ1-100\% treated

口Q1-70\% treated

Tamoxifen treated

FIGURE 5. Migration of H9-hNSC treated with (A) $25 \mu \mathrm{g} / \mathrm{mL}$ of QI-100\%, (B) $35 \mu \mathrm{g} / \mathrm{mL}$ of QI-70\%, (C) $10 \mu \mathrm{g} / \mathrm{mL}$ of tamoxifen and (D) non-treated H9-hNSC. Migrated H9-hNSC is indicated by black arrows. Magnification: 40X. (E) Quantification of migrated H9-hNSC. Each point represents average \pm SD of three independent experiments. There was no different in migration capacity among these cells, as compared to the non-treated control, indicated treatment with QI-100\%, QI-70\% and tamoxifen had no effects on H9-hNSC migration capacity 
compared to control (non-treated H9-hNSCs) (Figure 6; $p<0.05$ ), suggesting that the H9-hNSC not only migrate by itself, but it carries along the QI- $100 \%$ extract which induced the DBTRG-05MG cell death when it reaches the DBTRG-05MG. However, surprisingly, DBTRG-05MG treated with migrated $\mathrm{H} 9-\mathrm{hNSCs}$ preconditioned with tamoxifen (positive control) did not show significant cell reduction after migration assay. Considering that timing is an important factor for drug cytotoxicity effect, thus we postulated the cytotoxicity of Tamoxifen was limited by the shorter duration set for cell migration assay as compared to cytotoxicity assay ( $12 \mathrm{~h}$ vs. $72 \mathrm{~h}$ ). However, further detailed evaluation on the cell death mechanism induced by QI extracts, as well as tamoxifen, is necessary to confirm this.

\section{DISCUSSION}

Herbal medicines have been used for many decades and in fact, they are still being used in many developing countries as the primary source of medical treatment (Greenwell \& Rahman 2015). Recently, variety of bioactive compounds in traditional herbal plants had gained interest among researchers and was studied extensively to explore their potential medicinal effects scientifically. This is particularly important as until today, the usage of traditional herb by local community is still not well regulated and mostly is prescribed by non-physician, thus, causing a lot of associated risks and side effects (Greenwell \& Rahman 2015). Therefore, in this study, we opt to carefully investigate the major components in the QI plant and determine its cytotoxicity to human cells. We found that the QI plant studied in this research contains two major phenolic bioactive compounds which are TA and GA that can be extracted using soxhlet technique. However, an appropriate solvent must be carefully opted before running the soxhlet extraction because the extracted compound could vary depending on the type of solvent chosen. Methanol solvent was chose to extract phenolic compounds in this study because solubility of polyphenol is highest in methanol (Rao et al. 2013). The highest yield is commonly achieved by using sole methanol or their mixture with water. In this study, the effects of two different percentages of methanol (100\% vs. $70 \%)$ on the extract yield were performed. We found that in comparison of QI methanol extracts, $100 \%$ methanol extract (QI-100\%) had higher yield compared to $70 \%$ methanol extract (QI-70\%). Furthermore, free radical scavenging activity was also noticed higher in QI-100\% compared to QI-70\% methanol extract, meaning QI-100\% methanol extract had higher antioxidant activity compared to QI-70\% methanol extract. However, in this study, there was no significant different between the two. In order to further validate this finding, we quantified the bioactive compounds extracted in both QI methanol extracts using standard HPLC analysis (Sasidharan et al. 2011). Similarly, despite the HPLC analysis showed that QI-100\% methanol extract contained faintly higher percentage and concentration of TA and GA, the result was not significant. Taken all together, these data showed that extraction yield, antioxidant properties and phenolic compound yield from QI galls are not depending on the concentration of methanol solvents.

Nonetheless, in line with HPLC data which showed that both QI extracts (QI-100\% and QI-70\%) contained high amount of TA and GA, we found that these extracts also showed significant inhibitory effect on GBM cell line. The ability of QI methanol extracts to kill DBTRG-05MG indicated anti-proliferative property of QI towards glioma cells. This finding is much compatible with Hasmah et al. (2010) that mentioned about anti-proliferative properties of QI gall extracts against various cancer cells (Hasmah et al. 2010). On the other hand, both QI extracts showed low or even no toxicity to human normal brain glial and stem cells, proving its safety for treatment. Although the mechanism underlying the inhibition of cancerous cell growth by QI extracts is still under investigation, we postulated that this

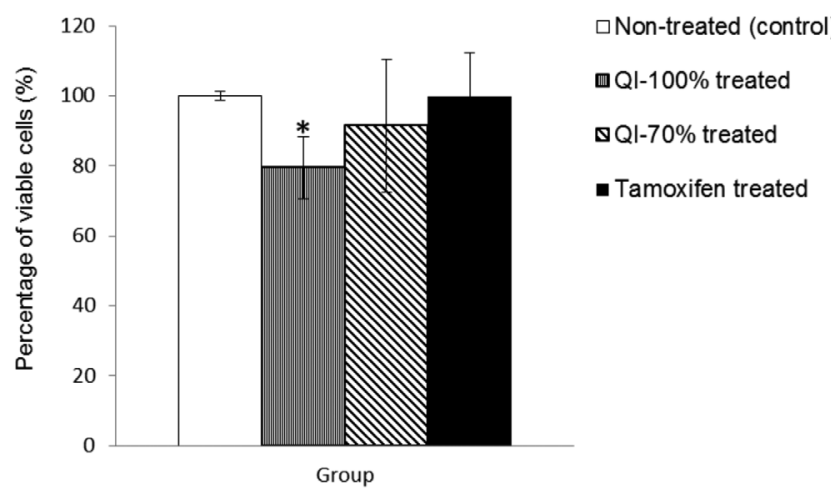

FIGURE 6. Effects of non-treated (control) and treated (QI-100\%, QI-70\% and tamoxifen) H9-hNSC on DBTRG-05MG cell viability after $12 \mathrm{~h}$ migration assay. Each point represents average \pm SD of three independent experiments. The viability of DBTRG-05MG cells were evaluated using MTT assay. DBTRG-05MG treated with migrated H9-hNSCs preconditioned with QI-100\% showed significant reduction in cell viability, compared to control (non-treated H9-hNSCs) ( $p<0.05$ vs. non-treated (control). However, there was no significant DBTRG-05MG cell reduction induced by tamoxifen-treated H9-hNSCs 
specific cytotoxicity effect could be due to the mechanism of the two major phenolic acids (TA and GA) found in QI plant. TA is a naturally occurring plant polyphenol, composed of a central glucose molecule derivatized at its hydroxyl groups with one or more galloyl residues, whilst GA is a trihydroxybenzoic acid which is widely distributed in green tea, red wine and grapes, oak bark, and other plants. A considerable amounts of experimental data on the antioxidant activity of both TA and GA with emphasis on structure-function antioxidant activity have been reported (Rao et al. 2013). The mechanism of antioxidant properties is mainly due to their hydrogen-donating and metal-chelating capacities which confer protection against Reactive Oxygen Species (ROS) which is elevated in almost all cancer types to promote many aspects of tumor development and progression. Therefore, reduction or detoxification of ROS in cancer cells by antioxidant compounds could help to inhibit cancer cell proliferation. Although extensive studies have been carried out on the inhibitory effect of phenolic acids against various cancers, to date, the $\mathrm{IC}_{50}$ for both brain cancerous cells (DBTRG05MG) and brain normal stem cells (H9-hNSC) and glial cells (SVG-p12) treated with QI-100\% and QI-70\% has not been published elsewhere.

Moreover, two clinically used chemotherapy drugs: the Temozolomide and Tamoxifen were also tested in this study. Temozolomide is now used worldwide to treat the GBM, as well as some other brain cancer types. In combination with radiotherapy, Temozolomide has become the international standard-of-care for thousands of people with this type of cancer (Villani et al. 2017). However, to our surprise, we found that the $\mathrm{IC}_{50}$ of Temozolomide was more than $100 \mu \mathrm{g} / \mathrm{mL}$ for DBTRG$05 \mathrm{MG}$, while $\mathrm{IC}_{50}$ of QI- $100 \%$ and QI-70\% was lower at 23 and $34 \mu \mathrm{g} / \mathrm{mL}$, respectively. This means that the potent of this clinical drug is less than the QI extracts, suggesting that the usage of this clinical drug for GBM treatment perhaps needs a re-evaluation and further investigation. Our suggestion is supported by Yoshino et al. (2010) study which testified that different malignant glioma cell lines exhibit different $\mathrm{IC}_{50}$ value for Temozolomide that ranged from 23.0 to $441.6 \mu \mathrm{M}$ (Yoshino et al.2010), showing that the efficiency of Temozolomide is tumor type-dependent and may not suitable for all types of brain cancers. On the other hand, the other clinical chemodrug, Tamoxifen, was found to be toxicity to both cancerous GBM cell line and normal brain NSC and glial lines at low concentration. This illustrated the non-specific feature of Tamoxifen inhibitory mechanism and its possibility to induce unwanted side effects to the patients.

Last but not least, there are many in vitro and in vivo studies demonstrated migration capacity of NSCs towards glioma as this unique feature can be useful as potential delivery agent of therapeutic drugs to eradicate glioma (Aboody et al. 2000; Heese et al. 2005). Nonetheless, to date, there is no published article on the migration of NSCs packaged with QI plant extracts towards glioma in vitro. In this study, we successfully demonstrated the migration capacity of H9-hNSCs towards DBTRG-05MG seeded in the lower chamber after treated with QI- $100 \%$ and QI-70\%, respectively. However, it is worth noting that this migration assay was performed on a Boyden migration chamber for $12 \mathrm{~h}$ only as any further migration duration could trigger unwanted migration by gravity force. Moreover, we also reported that H9-hNSCs treated with QI-100\% successfully reduced DBTRG-05MG cell number in lower chamber after $12 \mathrm{~h}$ migration. There are possibilities that H9-hNSCs penetrated the Boyden upper chamber membrane barrier into lower chamber with DBTRG-05MG cells and inhibited DBTRG-05MG cell growth with the QI-100\% extract. The migration of stem cell to cancer cell was mainly due to the chemotatic cytokines and signaling pathways (SDF-1/CXCR4 axis) involved in stem cell trafficking. Stromal-derived factor-1 (SDF-1) is an alpha-chemokine that binds to G-protein-coupled CXCR4, regulating the $\mathrm{CXCR}^{+}{ }^{+}$stem/progenitor cell migration to SDF-1 ${ }^{+}$glioma tumor (Vagima et al. 2011).

\section{CONCLUSION}

Here, we successfully demonstrated that QI $100 \%$ and $70 \%$ methanol extracts exhibited anti-proliferative properties against DBTRG-05MG cell line in vitro. Furthermore, migrated H9-hNSC cells towards DBTRG05MG cells in the modified Boyden chamber proved the unique feature of NSCs tropism to glioma. The novelty of this study was the evaluation of cytotoxicity effect of QI methanol extracts on human brain stem and cancer cells, as well as the migration capacity of human brain stem cell loaded with the optimum concentration of QI extracts towards human brain cancer cells in a modified Boyden chamber. This study showed that the NSCs were able to uptake and delivers QI plant extracts towards glioma and significantly reduced the glioma cell numbers in vitro. In conclusion, the use of NSC as delivery agent to deliver natural QI plant active compounds as anti-cancer drug for brain cancer chemotherapy could be possible and this has opened new possibilities for improvement of the quality of life of cancer patients.

\section{ACKNOWLEDGEMENTS}

This study was funded by the Ministry of Education Malaysia, Fundamental Research Grant Scheme (Grant no: 203/PPSK/6171154). The author Tan Suat Cheng and Lohis Balachandra had contributed equally to the findings reported in this paper. We thank Universiti Sains Malaysia for the support in granting permission to the investigators to use the space and assets belonging to the university during the process of conducting the research.

\section{REFERENCES}

Aboody, K.S., Brown, A., Rainov, N.G., Bower, K.A., Liu, S., Yang, W., Small, J.E., Herrlinger, U., Ourednik, V., Black, 
P.M., Breakfield, X.O. \& Synder, E.Y. 2000. Neural stem cells display extensive tropism for pathology in adult brain: Evidence from intracranial gliomas. Proceedings of the National Academy of Sciences 97(23): 12846-12851.

Agarwal, S., Sane, R., Oberoi, R., Ohlfest, J.R. \& Elmquist, W.F. 2011. Delivery of molecularly targeted therapy to malignant glioma, a disease of the whole brain. Expert Reviews in Molecular Medicine 13: e17.

Baharuddin, N.S., Abdullah, H. \& Abdul Wahab, W.N. 2015. Anti-Candida activity of Quercus infectoria gall extracts against Candida species. Journal of Pharmacy and Bioallied Sciences 7(1): 15-20.

Benedetti, S., Barbara, P., Bianca, P., Lorenzo, M., Maria, G.B., Dorotea, R., Rossella, G., Silvia, S., Francesco, D.M., Claudio, D.F., Angelo, V., Elena, C. \& Gaetano, F. 2000. Gene therapy of experimental brain tumors using neural progenitor cells. Nature Medicine 6(4): 447-450.

Greenwell, M. \& Rahman, P.K. 2015. Medicinal plants: Their use in anticancer treatment. International Journal Pharmaceurtical Science Research 6(10): 4103-4112.

Hasmah, A., Nurazila, Z., Chow, C.Y., Rina, R. \& Rafiquzzaman, M. 2010. Cytotoxic effects of Quercus infectoria extracts towards cervical (hela) and ovarian (caov-3) cancer cell lines. Health and the Environment Journal 1(2): 17-23.

Heese, O., Disko, A., Zirkel, D., Westphal, M. \& Lamszus, K. 2005. Neural stem cell migration toward gliomas in vitro. Neuro-oncology 7(4): 476-84.

Kornblum, H.I. 2007. Introduction to neural stem cells. Stroke 38(2): 810-816.

Nidhi, R., Sandhya, M., Sudhanshu. \& Ekta, M. 2013. In vitro phytochemical screening, antioxidant and antimicrobial activity of the methanolic extract of Quercus infectoria L. International Journal of Pharmacy \& Pharmaceutical Sciences 5(2): 273-277.

Nur Syukriah, A.R., Liza, M.S., Harisun, Y. \& Fadzillah, A.A.M.2014. Effect of solvent extraction on antioxidant and antibacterial activities from Quercus infectoria (Manjakani). International Food Research Journal 21(3): 1067-1073.

Ramirez, Y.P., Weatherbee, J.L., Wheelhouse, R.T. \& Ross, A.H. 2013. Glioblastoma multiforme therapy and mechanisms of resistance. Pharmaceuticals (Basel) 6(12): 1475-506.

Sasidharan, S., Chen, Y., Saravanan, D., Sundram, K.M. \& Latha Yoga, L. 2011. Extraction, isolation and characterization of bioactive compounds from plant's extracts. African Journal of Traditional, Complementary and Alternative Medicines 8(1): $1-10$
Shaikh, I., Ali, S., Tariq, M., Chaudhary, S.S., Aslam, A. \& Ghani, H. 2013. Oak galls: The medicinal balls. Journal of Pharmaceutical \& Scientific Innovation 2(1): 18-21.

Shrestha, S., Kaushik, V.S., Shwarappa, R.S.E., Subaramaihha, S.R., Ramanna, L.M. \& Lakkappa, D.B. 2014 Pharmacognostic studies of insect gall of Quercus infectoria olivier (Fagaceae). Asian Pacific Journal of Tropical Biomedicine 4(1): 35-39.

Vagima, Y., Lapid, K., Kollet, O., Goichberg, P., Alon, R. \& Lapidot, T. 2011. Pathways implicated in stem cell migration: The SDF-1/CXCR4 axis. Methods Mol. Biol. 750: 277-289.

Villani, V., Merola, R., Vidiri, A., Fabi, A., Carosi, M., Giannarelli, D., Marucci, L., Maschio, M., Carapella, C.M. \& Pace, A. 2017. Temozolomide low-dose chemotherapy in newly diagnosed low-grade gliomas: Activity, safety, and long-term follow-up. Tumori 103(3): 255-260.

Yoshino, A., Ogino, A., Yachi, K., Ohta, T., Fukushima, T., Watanabe, T., Katayama, Y., Okamoto, Y., Naruse, N., Sano, E. \& Tsumoto, K. 2010. Gene expression profiling predicts response to temozolomide in malignant gliomas. International Journal of Oncology 36(6): 1367-1377.

Zhang, X., Zhang, W., Cao, W.D., Cheng, G. \& Zhang, Y.Q. 2012. Glioblastoma multiforme: Molecular characterization and current treatment strategy (review). Exp. Ther. Med. 3(1): 9-14.

Biomedicine Programme

School of Health Sciences

Universiti Sains Malaysia

11800 Gelugor, Penang

Malaysia

*Corresponding author; email: tansc@usm.my

Received: 1 October 2017

Accepted: 5 February 2018 